\title{
The Existence of the Manuscript in Minangkabau Indonesia and Its Field in Islamic Studies
}

\author{
Taufiqurrahman, ${ }^{*}$ Ahmad Taufik Hidayat, ${ }^{* *}$ Efrinaldi, ${ }^{, * *}$ Sudarman ${ }^{* * * *} \&$ Lukmanulhakim ${ }^{* * * * *}$
}

\begin{abstract}
The existence of manuscripts in the Minangkabau area has undergone a development that is not only in certain surau but can even be found in various places in Minangkabau. The text of the manuscript is generally related to Islamic studies, so that the direction of the scientific field of study will support scientific development in the fields of hadìth, shari'a, history, Islamic education and the development of thought, philosophy (mantīq), and Sufism. This study uses primary data derived from existing manuscripts with philology and codicology approaches. This approach uses manuscripts as research sources to be presented in a mapping which has been identified that philology, codicology, and paratext studies are the initial bases in studying aspects of the text in Minangkabau manuscripts. On this basis, Islamic studies institutions have a great opportunity to study the most important aspects of the manuscript or to use the manuscript as the main source. This is related to the study of manuscripts in the development of hadìth studies, development of shari'a studies, development of historical studies, development of Islamic education and thought, philosophy (mantīq), and Sufism.
\end{abstract}

Keywords: Islamic studies, Islamic studies institutions, manuscripts, scientific development, the student interest

\section{Introduction}

In the 2007 Republic of Indonesia law on libraries, the second part of article 7 paragraph (1) d, states that the state guarantees the availability of a diversity of library collections through translation, transliteration, transfer of voice to writing (transcription), and media transfer (transmedia). As a form of appreciation from the state, the government gives rewards to people who have given attention and preserved the manuscript (old manuscripts). ${ }^{1}$ Preservation efforts (in a broad sense) in this study welcomed the appeal of the government as set out in the law above.

Manuscripts are intellectual products from the past which are passed on to present society. The texts written therein were born through a series of creative processes of past writers, such as scholars, writers, thinkers, and scientists who tried to express their ideas, concepts, and works in the past as well as concrete documentation from their efforts. Therefore, reviewing it in a study is a further effort than just preservation, but also revitalizing the noble values that have been developed by the ancestors of the Indonesian. ${ }^{2}$ The effort to study manuscripts in Indonesia that accounted for up to tens of thousands is still very minimal, it can be seen from the relatively small interest of students towards this cultural heritage object. The sources of studies provided by manuscripts are sufficient to meet the various scientific disciplines that exist in Islamic studies institutions, especially those related to Islamic studies. The content of the Minangkabau Manuscript in particular and the Malay manuscripts in general covers the following fields of study: ${ }^{3} 1$ ) The Qur'an (mușhaf) and

\footnotetext{
* Taufiqurrahman (Corresponding Author), Senior Lecturer, Department of Aqidah and Filsafat Islam, Faculty of Ushuluddin and Studi Agama, Universitas Islam Negeri Imam Bonjol Padang, Sumatera Barat, Indonesia. Email: taufiqurrahman@uinib.ac.id.

** Ahmad Taufik Hidayat, Lecturer, Department of history of Islamic civilization, Faculty of Adab and Humaniora, Universitas Islam Negeri Imam Bonjol Padang, Sumatera Barat, Indonesia. Email: ahmadhidayat@uinib.ac.id.

**** Efrinaldi, Senior Lecturer, Department of Jinayah Siyasah, Faculty of Syariah, Universitas Islam Negeri Imam Bonjol Padang, Sumatera Barat, Indonesia. Email: efrinaldi@uinib.ac.id.

**** Sudarman, Lecturer, Department of history of Islamic civilization, Faculty of Adab and Humaniora, Universitas Islam Negeri Imam Bonjol Padang, Sumatera Barat, Indonesia. Email: sudarmanma@uinib.ac.id.

****** Lukmanulhakim, Lecturer, Department of history of Islamic civilization, Faculty of Adab and Humaniora, Universitas Islam Negeri Imam Bonjol Padang, Sumatera Barat, Indonesia. Email: lukmanulhakim@uinib.ac.id.

${ }^{1}$ Republik Indonesia (2007), “Undang-undang Tentang Perpustakaan,” Jakarta.

${ }^{2}$ Fuad Jabali (2014), "Irsā Al-Usus al-'Ilmīyah Li al-Dirāsat al-Islāmīyah: Al-Taṭawwur al-Akādīmī Li al-Jāmi’at al-Islāmīyah alHukūmīyah Wa al-Ma’āhid al-Islāmīyah al-Ḥukūmīyah al-'Ulyā bi Indūn̄̄sīyā,” Studia Islamika, Vol. 9, No. 2, pp. 121-146; Oman Fathurahman (2014), “Tradisi Intelektual Islam Melayu-Indonesia: Adaptasi dan Pembaharuan," Studia Islamika, Vol. 8, No. 3, pp. 207222; .Ahmed Ibrahim Abushouk and Hassan Ahmed (eds.) (2009), The Hadhrami Diaspora in Southeast Asia: Identity Maintenance or Assimilation?, Leiden and Boston: Brill.

${ }^{3}$ Oman Fathurahman (2013), “A Textual Approach to Understanding Nusantara Muslims," Studia Islamika, Vol. 20, No. 1, pp. 179-182; Titik Pudjiastuti (2006), Naskah Dan Studi Naskah: Sebuah Antologi, Cimanggis, Bojonggede, Bogor: Akademia, pp. 88-168.
} 
interpretation; 2) Ḥadīth; 3) Fiqh; 4) Arabic (grammar); 5) Literature; 7) Sufism/țariqa; 8) History; 9) Islamic constitutional law; 10) Mujārabāt (traditional remedy); 11) Letters; 11) Thought and philosophy (mantịq).

When explored further, the various branches and content above also contain broad and interconnected aspects. For example, in the text of Sufism, there are studies relating to philosophy, hadith, interpretation, history, language, literature, and others. This kind of interrelationship is interpreted as a combination of the utility function or spiritual perfection function of Braginsky's version with the function of solace. ${ }^{4}$ Thus, Islam in various aspects of its teachings recorded in the manuscript has developed widely in various intellectual experiences of Muslim societies in the past. ${ }^{5}$ This kind of self-awareness can be explored within the framework of scientific discipline which develops in Islamic higher education or Islamic study institution which later can be used as important resources within both lecturers and students' research. So far the research conducted by the lecturer, researcher, and the student has yet optimum in exploring Minangkabau manuscripts along with their aspects. Therefore, this research aimed to help to provide manuscript data for lecturer, researcher, and student in Islamic higher education or Islamic study institute, by offering relevant mapping toward many fields of this form of self-awareness can be explored within the framework of scientific disciplines developed in Islamic higher education or Islamic study institutions, which can later be used as important sources in the research of lecturers, and students. Conversely, so far the research produced by lecturers, researchers, and students has not explored Minangkabau manuscripts in various aspects. This form of self-awareness can be explored within the framework of scientific disciplines developed in Islamic studies institutions, which can later be used as important sources in the research of lecturers, and students. Conversely, so far the research produced by lecturers, researchers, and students has not explored Minangkabau manuscripts in various aspects. Thus this research is intended to help provide data on manuscripts for lecturers, researchers, and students in Islamic studies institutions, by offering relevant mapping in several fields of study in Islamic studies institutions that refer to objects, content, locus, thought of scholars, and writers of the past.

Based on the background above, the main problem that will be examined in this study is how to map Minangkabau manuscripts for the development of research-based studies in Islamic studies institutions. Thus, the focus of this research is directed at answering the existence of the Minangkabau manuscript in the religious field; the existence of Minangkabau manuscripts in the general field; and research the existence based on Minangkabau manuscripts for scientific disciplines in Islamic studies institutions.

\section{Theoretical Review}

The terms manuscripts (Dutch: handscrift; Arabic: nuskhah al-makhtütah) is generally understood as handwritten works; old literature; or contain old cultural concepts. The 2008 edition of the Indonesian Language Dictionary defines "handwritten manuscripts, whether by pen, pencil or typed (not printed)." As for the context of this research, the term of the manuscript is the handwritten works of copyists, writers, litterateur, thinkers, and scholars. While manuscripts are written documents passed down to humans today, which contain information about human life centuries ago.

As a legacy of the past, Islamic manuscripts grow and develop in a civilization of texts (hadarah alnaș) that starts from the first text of the Qur'an, then later the hadīth, and so on develops and metamorphoses into subsequent texts, even approximately 15 centuries of Islamic texts have composed dialogue with a variety of cultures and time spectrum. ${ }^{7}$ In the 13th Annual International Conference of Islamic Studies (AICIS) in 2013 in Mataram, West Nusa Tenggara, with the theme Distinctive Paradigm of Indonesian Islamic Studies: Towards Renaissance of Islamic Civilization. The recommendation from this scientific meeting is the importance of Islamic treasures in the form of

\footnotetext{
${ }^{4}$ Vladimir Braginsky (1998), Yang Indah Berfaedah dan Kamal, Sejarah Sastera Melayu dalam Abad 7-19, Jakarta: INIS, pp. xxviii-xxix; Yusri Akhimuddin (2012), "Naskah (Asal Khilaf Bilangan Taqwim): Relasi Ulama-Umara di Minangkabau Abad Ke-17 dalam Penetapan Awal Ramadan," Manuskripta, pp. 79-101.

5 Sudibyo (2007), "Kembali Ke Filologi : Filologi Indonesia," Humaniora, Vol. 19, No. 2, 107-118.

${ }^{6}$ Syauqi Dhaif (2008), al-Mu jam al-Wasit, IV, Mesir: Maktabah asy-Syauqi al-Dauliyah, p. 955; D Sugono (2008), Kamus Bahasa Indonesia, 4th ed., Jakarta: Pusat Bahasa Depatemen Pendidikan Nasional, p. 987.

${ }^{7}$ Nasr Hamid Abu Zaid (2003), Tekstualitas Alquran, Kritik Terhadap Ulum Alquran, Yogyakarta: LkiS, p. 1.
} 
manuscripts to get more attention from today's academics, especially in the PTIN/UIN (State Islamic University) environment under the Indonesian Ministry of Religion. ${ }^{8}$ That is, the result of reflection from the long experience of the Indonesian Muslim community on Islam and values in various aspects of its teachings recorded in ancient manuscripts, developed widely in various intellectual experiences of Muslim societies in the past.

Intellectual study in the past is a historical aspect of the manuscript which is recorded in the physical form of the manuscript, such as the base of the manuscript, cover, ink, scriptorium, as well as the history of the manuscript in carrying out the tasks of Philology until now still attached to Codicology. ${ }^{9}$ This close relationship is often misinterpreted that this study is a part of Philology. In its development, Codicology can also be used for further excavation purposes, such as layout, stamps, writing, and language. ${ }^{10}$

In connection with the mapping of script sources for the development of Higher Education, there are many important studies. Oman Fathurahman for example in Filologi dan Islam Indonesia, (2010), ${ }^{11}$ has tried to map textual studies in the archipelago based on Philology. The focus of Oman's studies is the application of philological studies and their aspects in many State Islamic Universities in Indonesia. The vastness of the treasury of the archipelago seems not to have an adequate place in academic studies in some Islamic-based tertiary institutions. Similarly, Agus Iswanto has written in the al-Qalam Journal entitled "Kecenderungan Kajian Manuskrip Keislaman di UIN Syarif Hidayatullah Jakarta (2015)." ${ }^{12}$ In this article, Iswanto collects data and groupings of studies that have been conducted by students of UIN Syarif Hidayatullah Jakarta. Therefore, the basis of Iswanto's study is a review of several manuscript study models that have been conducted by UIN Syarif Hidayatullah students.

\section{Methodology}

This research is qualitative research to map manuscripts. In this case, there are three main components that the researcher will pass, namely data reduction, data display, and conclusion drawing. ${ }^{13}$ Data are collected from texts found throughout the Minangkabau area that obtained from scriptorium such as surau, madrasa, museum, National Library of Indonesia and Andalas University Library, Minangkabau Culture Documentation and Information Center, historical places (Kutub Khazanah H. Abdul Karim Amrullah: HAKA; Yayasan Bani Latif), and individual societies who kept the manuscript. This data search is associated with; 1) Sufism and philosophy, 2) religion, 3) language, literature, and history, and 4) constitution and laws. These texts are mapped and identified based on predetermined categories. The approach taken is the philological and codicological approaches. Philology is used not in the context of presenting a full edition of the manuscript, but to review and verify the text contained in the manuscript. Meanwhile, codicology is intended to describe the text. ${ }^{14}$ Furthermore, the data analysis is done descriptively. The steps taken are as follows: first, data collection. Second, data interpretation. Third, writing. ${ }^{15}$

\footnotetext{
${ }^{8}$ Dede Hidayatullah (2017), "Naskah Ilmu Ma'rifatullah: Kodikologi, Suntingan, Struktur, dan Isi Teks," METASASTRA: Jurnal Penelitian Sastra, Vol. 9, No. 2, pp. 107-116; Agus Iswanto (2016), "Kecenderungan Kajian Manuskrip Keislaman Di Uin Syarif Hidayatullah Jakarta," al-Qalam, Vol. 21, No. 1, pp. 161-171.

${ }^{9}$ Oman Fathurahman (2003), "Filologi dan Penelitian Teks-teks Keagamaan," Buletin al-Turas, Vol. 9, No. 2, pp. 1-16; Siti Baroroh Baried (1994), Pengantar Teori Filologi, cet. II., Yogyakarta: Badan Penelitian dan Publikasi Fakultas Sastra, Universitas Gadjah Mada; Oman Fathurahman (2015), Filologi Indonesia: Teori dan Metode, cet. 1, Jakarta: Prenadamedia Group; Khabibi Muhammad Luthfi (2016), "Kontekstualisasi Filologi dalam Teks-teks Islam Nusantara," Jurnal Kebudayaan Islam, Vol. 14, No. 1, pp. 114-128.

${ }^{10}$ Titik Pudjiastuti (2007), "Kajian Kodikologis Atas Surat Sultan Kanoman, Cirebon (COD. OR. 2241 ILLB 17 (No. 80)," Wacana, Journal of the Humanities of Indonesia, Vol. 9, No. 1; Dede Hidayatullah, "Naskah Ilmu Ma'rifatullah," pp. 107-116.

${ }^{11}$ Oman Fathurahman (2010), Filologi dan Islam Indonesia, Jakarta: Kementerian Agama. Badan Penelitian (Litbang) dan Pendidikan Pelatihan (Diklat). Pusat Penelitian Pengembangan (Puslitbang) Lektur Keagamaan).

${ }^{12}$ Agus Iswanto (2016), “Kecenderungan Kajian Manuskrip Keislaman Di Uin Syarif Hidayatullah JakartA,” al-Qalam, Vol. 21, No. 1, pp. 161-171.

${ }^{13}$ Christine R Marlow (2010), Research Methods for Generalist Social Work, Cengage Learning, p. 223; Heribertus Sutopo (1988), Pengantar Penelitian Kualitatif: Dasar-dasar Teoritis dan Praktis, Surakarta: UNS Press, p. 34.

${ }^{14}$ Baried (1994), Pengantar Teori Filologi; Nabilah Lubis (1996), Naskah, Teks, dan Metode Penelitian Filologi, Fakultas Adab IAIN Syarif Hidayatullah: Forum Kajian Bahasa \& Sastra Arab; Fathurahman (2015), Filologi Indonesia: Teori dan Metode; Fathurahman, "A Textual Approach to Understanding Nusantara Muslims," pp. 179-182.

${ }^{15}$ Lexy J. Moleong, Metode Penelitian Kualitatif, Bandung: Remaja Rosdakarya, p. 4.
} 


\section{Development of Manuscript Texts in Minangkabau}

Even in the 17-18 century AD, in the surau that became the network of the tariqa Naqshabandiyah and Shatariyah there were several books which became the main references such as; the reference book for sarf study is Kitab Dammun, for nahwwī studies is al-'Awāmil, al-Fawākih al-Jāniyyah Sharah Mutammimah al-Jurumiyyah, for moral studies is al-Hikàm, for hadìth studies is Shu'b alImān, for 'aqīdah study is Umm al-Barāhīn and al-Mufìd Sharah Matān Sanusi, for fiqh studies is Minhāj al-Ṭālibìn, Syarah Mahalli 'ala Minhāj al- Țālibìn, and al-Taqrīb Liyantafi'u bihi alMubtadi', for tafsīr studies is al-Jalālain, for Sufism in the țariqa Shațariyah is Tanbīh al-Mashi' alMansūb ila Tarīq al-Qushashiy with the author 'Abdurrauf 'Ali al-Jawi, and the book Kitāb Tadhkīr $a l-G h \bar{a} b \bar{\imath} y$ karya from Sheikh Burhanuddin. ${ }^{16}$

Based on the distribution of the reference books above, there is a tendency for the books used by the sheikhs in the tariqa Shatariyah to have similarities, this is because all of these sheikhs have studied with the main sheikh of the tariqa Shatariyah, Sheikh Burhanuddin Ulakan. From the knowledge taught by the Shatariyah sheikhs, it is seen that the knowledge they teach includes multi-disciplinary Islamic studies, not only fixated in the tariqa studies. This was done by Sheikh Burhanuddin because he wanted all his followers to carry out the shari'a entirely, not to separate the tariqa and the shari'a. The books taught are the basis of the Islamic education curriculum in Minangkabau and some of these books still exist in the world of Islamic boarding schools in Minangkabau.

So far, many Islamic studies institutions are relatively far behind in the aspects of studying manuscripts or using manuscripts as the primary source of a study or research. There are so many manuscripts in Minangkabau. However, not many study the manuscript as an abundant Islamic study resource in Minangkabau. Some areas that reserve manuscripts in Minangkabau have competence as objects of study by Islamic studies institutions, such as the collection of manuscripts in three regencies in West Sumatra; Pariaman, West Pasaman, and Agam. Several types of manuscripts stored in one of the three regencies mentioned above are classified into several themes such as:

Table 1. Tafsīr and Hadīth

\begin{tabular}{|c|c|c|c|}
\hline No & Title of Manuscript & Category & Repository \\
\hline 1. & Kitāb al-Jalālain & Tafsīr & Adityawarman Museum Padang. \\
\hline 2. & Tafsīr Yā Ayyuha al-Nās & Tafsīr & Agam. \\
\hline 3. & Tafsìr Yā Ayyuha Alladhina Āmanū & Tafsīr & Agam. \\
\hline 4. & Tafsìr Wa Min al-Nās & Tafsīr & Agam. \\
\hline 5. & Kitāb Hișf al-Qāriy & Ilmu Qirā'at & Surau Pondok Ulakan Pariman. \\
\hline 6. & Kitāb Riyāọ al-Ṣālihin & Hadìth & Adityawarman Museum Padang. \\
\hline 7. & Kitāb Bayān al-Nāsikh wa al-Mansūkeh & Ilmu Nāsikh & Surau Pondok Ulakan Pariman. \\
\hline
\end{tabular}

Table 2. Shari'a

\begin{tabular}{|c|c|c|c|c|c|c|}
\hline No & Title of Manuscript & Category & \multicolumn{4}{|c|}{ Repository } \\
\hline 1. & 'Adāb Jima $\bar{a} '$ & Fiqh & Surau & Lubuk & Landur & West \\
\hline 2. & Bab al-Nikāh & Fiqh & 'asaman. & & & \\
\hline 3. & Kitāb Buruan dan Sembelihan & Fiqh & Surau & Lubuk & Landur & West \\
\hline 4. & Kitāb 'Ibādah & Fiqh & 'asaman. & & & \\
\hline 5. & Kitāb Șalat dan Șaum & Fiqh & Surau & Lubuk & Landur & West \\
\hline 6. & Kitāb al-Janā'iz dan Zakāt & Fiqh & 'asaman. & & & \\
\hline 7. & Kitāb Puasa & Fiqh & Surau & Lubuk & Landur & West \\
\hline 8. & Kitāb Buruan & Fiqh & 'asaman. & & & \\
\hline 9. & Kitāa Jināyah (Pidana) & Fiqh & Surau & Lubuk & Landur & West \\
\hline 10. & Kitāb Sujūd Sahwī & Fiqh & 'asaman. & & & \\
\hline 11. & Kitāb Șalat & Fiqh & Surau & Lubuk & Landur & West \\
\hline 12. & Fath al-Qarīb al-Mujīb & Fiqh & 'asaman. & & & \\
\hline
\end{tabular}

16 Oman Fathurahman, Filologi Indonesia: Teori dan Metode; Oman Fathurahman (2003), "Reinforcing Neo-Sufism in the MalayIndonesian World: Shaț̣ārīyah Order in West Sumatra," Studia Islamika, Vo. 10, No. 3, p. 29-93. 


Surau Lubuk Landur West
'asaman.
Surau Lubuk Landur West
'asaman.
Surau Lubuk Landur West
'asaman.
Surau Lubuk Landur West
'asaman.
Surau Pondok Ulakan Pariaman.
Surau Pondok Ulakan Pariaman.

Table 3. Islamic Thought, Philosophy, and Logic

\begin{tabular}{|c|c|c|c|}
\hline No & Title of Manuscript & Category & Repository \\
\hline 1. & Kitāb Tadhkīr al-Ghābīy & Ușulūddin & Surau Pondok Ulakan Pariman. \\
\hline 2. & Kitāb Ițāf al-Dhākīy & Ușulūddin & Surau Pondok Ulakan Pariman. \\
\hline 3. & Kitāb Akidah Lima Puluh & Ușulūddin & Surau Lubuk Landur West Pasaman. \\
\hline 4. & Bidāyat al-Hidāyat & Tasāwuf & Surau Lubuk Landur West Pasaman. \\
\hline 5. & Kitāb Sifat Dua Puluh & Tawhīd & Surau Lubuk Landur West Pasaman. \\
\hline 6. & Kitāb Sifat Dua Puluh & Tawhīè & Surau Lubuk Landur West Pasaman. \\
\hline 7. & Risālah Ușuluddin & Ușulūddin & Surau Lubuk Landur West Pasaman. \\
\hline 8. & Kitāb Tawhīd & Tawhīd & Surau Lubuk Landur West Pasaman. \\
\hline 9. & 'Umdat al-Muhtāaj & Tawhīd & Surau Pondok Ulakan Pariman. \\
\hline 10. & Kifāyat al-Muhtajīn ila $\Lambda$ & & \\
\hline & Mawhidīn biy Wahdat al- & Ușulūddin & Surau Pondok Ulakan Pariman. \\
\hline 11. & Ilmu Tawhīd & Tawhịid & Surau Pondok Ulakan Pariman. \\
\hline 12. & Kitāb Shu'b al-Imān & Tawhīi & Surau Pondok Ulakan Pariman. \\
\hline 13. & Sharh Matn al-Sanusi & Tawhīè & Surau Pondok Ulakan Pariman. \\
\hline 14. & Kitāb Tawhīd & Tawhīed & Surau Pondok Ulakan Pariman. \\
\hline 15. & Kitāb Mantīq & Logic & Surau Pondok Ulakan Pariman. \\
\hline
\end{tabular}

Table 4. Arabic History and Grammatical

\begin{tabular}{|c|c|c|c|}
\hline No & Title of Man & Category & Repository \\
\hline 1. & Tambo Minangkbau & History & Surau Pondok Ulakan Pariaman. \\
\hline 2. & 'Umdāt al-Ansāb & Hist & Surau Pondok Ulakan Pariaman. \\
\hline 3. & Awāmil al-Jurumiyah & Nahwu & Surau Lubuk Landur West \\
\hline 4. & Kitāb Nahwu & $\mathrm{Nah}$ & Pasaman. \\
\hline 5. & Kitāb Nahwu dan Sarf & Nahwu & Surau Pondok Ulakan Pariaman. \\
\hline 6. & Kitāl & Sarf & $\mathrm{k}$ Ula \\
\hline 7. & l-Burhāniyyah & Nahwu & Sur: \\
\hline 8. & Mashruh al-Mawāzinn fiy Sharh al- & Șa & Surau Pondok Ulakan Pariaman. \\
\hline 9. & Mizān & Șarf & Surau Pondok Ulakan Pariaman. \\
\hline \multirow[t]{2}{*}{10.} & Alfiyyah Ibn Mālik & Naḥwu & Surau Pondok Ulakan Pariaman. \\
\hline & Kitāb Tașrīf Mufradāt & Nahwwu & Surau Pondok Ulakan Pariaman. \\
\hline
\end{tabular}

Utilization of the Minangkabau Manuscript for the Development of Studies Discipline in Islamic Studies Institutions

\section{Manuscript Study of Hadīth}

Seeing at the development of Hadīth studies in Minangkabau based on the existence of manuscripts, the study conducted is still lacking. This is because manuscripts that talk about the study of hadith are very minimal to be found. Until now, there have not been found any manuscripts that talk about what

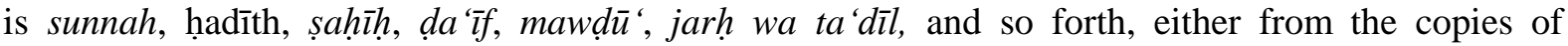
manuscripts by Middle Eastern scholars or local scholars. ${ }^{17}$ Based on this it can be seen that the Minangkabau people at the beginning of the development of Islam relied on their belief in the ulama who were seen as experts in the field of religion, such as:

\footnotetext{
${ }^{17}$ Saifuddin Zuhri Qudsy (2016), “Living Hadis: Genealogi, Teori, Dan Aplikasi,” Jurnal Living Hadis, Vol. 1, No. 1, p. 177-196.
} 
(At-Tirmidhiy stated): After telling us the Qutaibah (he said) had told us Risydin bin $\mathrm{Sa}^{\text {'d }}$ from Abdurrahman bin Ziyād bin An'um from 'Utbah bin Humaid from 'Ubadah bin Nusaiy from Abdurrahman bin Ghonm from Muadz bin Jabal, he said: I see Prophet Șallallahu 'alaihi Wasallam when he finished ablution he wiped his face with the hem of his clothes (HR. at-Tirmidhīy).

Then explain the benefits that will be obtained if the prayer in this hadīth is read:

\begin{abstract}
Who wants to see the Messenger of Allah in his dream on Friday night then take a shower (b-r-s-ny-m-h) and take water to pray then pray two rak'ah, then give greetings and recite this prayer five times with the sincerity of his heart, then sleep intending and he said "O my God, meet me with the Messenger of Allah then convey Allah ta'ala this blessing. So whoever lacks his sustenance, then reciting this prayer, Allah ta'ala will surely make it easier for him because of this prayer, whoever owes a lot or he (kjt) or his illness, then recite this prayer will be lightened by Allah and will be given (skjt) given by Allah ta'ala because of this prayer, if a hafizh wants to read the Qur'an then take umbar and musk and genggang then wash the three teak stones make da'awat then the letter in a white bowl then drink seven in the morning, will surely be given by Allah hafizh because of this prayer. If a person dies, then write on his shroud, Allah will lighten his tongue when he meets Munkar and Nakir (h-a) and Allah and the angels praise his grave and the light of his grave thanks to this prayer. If a person runs away, then pray four rak'ahs with sincerity of heart, then each rak'ah is recited fatihah three times and alikhlas three times already, then ask for prayers to Allah ta'ala will surely be his servant because of this prayer. If a sick person or a sailor reads this prayer he will surely be faithful to God because of this prayer" (Manuscript in Adityawarman Museum Padang). ${ }^{18}$
\end{abstract}

Based on the explanation above, then in the study of hadith through the text is rarely found in Minangkabau; the religious practices considered by the Minangkabau community to be sourced from the hadīth of the Prophet are very much found. The practice does not emphasize the isnād (citations) contained in the hadīth, but only focuses on the content of the hadīth. ${ }^{19}$ Whether the hadìths are da îf

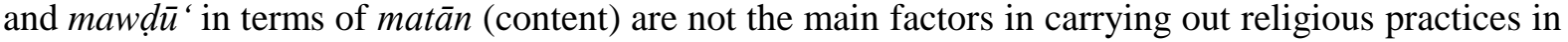
Minangkabau. This is evidenced by the discovery of some hadith quotations that are not mentioned $i s n \bar{a} d$, but these traditions are believed and practiced in Minangkabau. Even some of these hadīth quotations spread to several manuscripts in different areas in Minangkabau. Examples of gharīb ḥadīth spread in Minangkabau.

\title{
Manuscript Study of Shari 'a Knowledge
}

In the development of shari'a studies in Indonesia, the existence of manuscripts (ancient manuscripts) appears as an intellectual product that was passed on to the next Muslim community. The texts written in the manuscript were born through a series of creative processes of fiqh scholars or writers of the past who tried to express thoughts, ideas, concepts, and works of the past. The traces written in it are concrete evidence of their efforts in this regard. Therefore, analyzing and reviewing it in a study is a further effort than just preservation, but also revitalizing the noble values that have been developed by the Indonesian archipelago scholars or the ancestors of the Indonesian people in general.

Various attempts to study the manuscripts in the field of Shari'a or ancient texts totaling tens of thousands in Indonesia are still lacking. ${ }^{20}$ In Islamic studies institutions, students' interest in the study of manuscripts or objects of cultural heritage is relatively small. The sources of studies provided by the manuscript quite meet various studies disciplines, including studies in the field of fiqh, especially those relating to Islamic studies in general.

\footnotetext{
${ }^{18}$ Observation and Personal Interview with Buya Ismet, $19^{\text {th }}$ October 2019, Surau Manggopoh Agam.

${ }^{19}$ Barbara Daly Metcalf (1993), "Living Hadìth in the Tablīghī Jama'āt," The Journal of Asian Studies, Vol. 52, No. 3, pp. 584-608.

${ }^{20}$ Oman Fathurahman, Filologi dan Islam Indonesia, p. vii.
} 
In the fiqh study, many texts in the collection of manuscripts of Surau Pondok Ulakan Pariaman are categorized into Islam jurisprudential group of Madhhab Shāfi'īy. Generally, fiqh texts in this context are containing worships practical guides and not too deep. Therefore, in this collection, the ext of Minhāj al-Ṭâlibīn by al-Nawawìy which is pretty deep Shāfi'īyah text is nowhere to be found. Usually, Minhaj text can be found in surau that existed before the XX century. In this context, elaborating manuscript literature of fiqh field study is very urgent to be brought into sustaining research and study.

For example the manuscript of sharah to the book of Matn al-Taqrīb (Ghäyat al-Ikhtishār), a popular text about Shāfi'īyah fiqh written by Husein ibn Ahmad al-Asfahanīy (d. $488 \mathrm{H}$ ) or better known as Imām Abi Suja'. ${ }^{21}$ The Book of Matn al-Taqrīb and its sharah, entitled Fath al-Qarīb, are fiqh works that are widely studied in Southeast Asia. One of the reasons why this work is so popular is the discussion is fairly systematic and complete. In the preamble of shari'a, Imām Muhammad Ibn Qāsim explained the selection of the title of his work as follows:

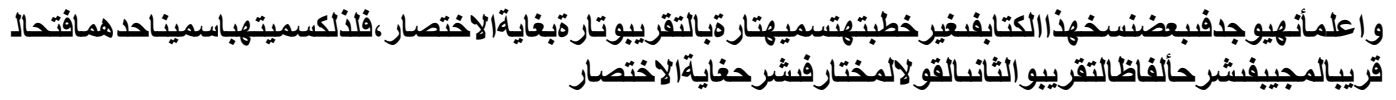

Know, it is found in some of these manuscripts (matn), in addition to the preface, that this book is sometimes named al-Taqrīb, and at other times it is named Ghāyat alIkhtishār. Therefore I also named this sharah with two names, first Fath al-Qarīb alMujīb fiy Sharh Alfaẓ al-Taqrīb, second al-Qawl al-Mukhtār fiy Sharh Ghāyat alIkhtishār.

Figure 1. Page of Script no. 05/SP/SLH/2012

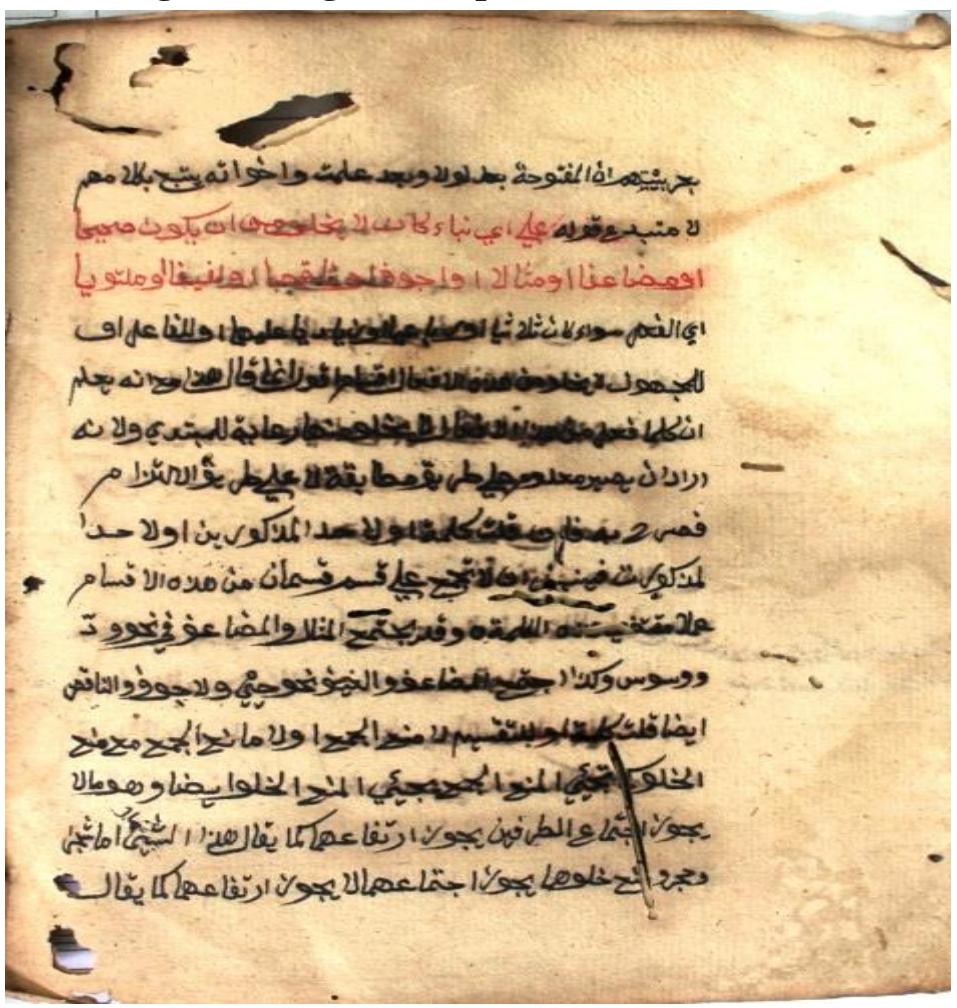

The script itself has no cover on it and there are holes in most parts of the script text. Moreover, each edge of the text is perforated since termite has eaten them. The text was written by using pretty neat khat riq'ah. The ink used is black with rubrics and the description of the content is that this script consists of 4 different texts. Meanwhile, the other text is in good condition, however, some pages are damaged due to the expanding ink and hole. This text has no cover, most of the pages are missing, and part of the ink in the text is expanding. The text was written by using black ink with rubrics, and the khat employed can be grouped as not a very neat naskhiy but it is readable. In the preface part of

${ }^{21}$ Haji Khalifah (n.d.), Kashf al-Zunnun 'an Asami al-Kutub Wal al-Funun, Volume II, Beirut: Dar Ihya' al-Turath al-'Araby, p. 1189. 
the text, there is a word "al-Burhānīy". This indicated that the following text is related to the other text in this surau collection, namely, Tașrîf al-Burhānīy and Risālah al-Burhāniyah texts. The Writer, al-Sheikh al-Imām al-'Ālim al-'Allamah al-Muhaqqiq al-Fahamah Shams al-Millah wa al-Din Abu 'Abdillah Muhammad Ibn Qasim Shāfi'īy, entitled as al-Ghāziy (w. 1097 H). ${ }^{22}$

\section{Manuscript Study of Historical Studies}

Oman Fathurahman, ${ }^{23}$ a talented young researcher who studies the old Minangkabau manuscripts, showed that Minangkabau surau, as with religious institutions (churches) in the Western, have a tremendous amount of religious manuscripts and this is of great value for historical research. Most of its contents relate to the problem of Sufism, nahwwu and șarf, and tafsīr. Religious texts generally show the line of development and distribution of Islamic religions that are tariqa (Sufism). This process takes place systematically through the surau. This relationship is inseparable from the surau which plays an important role as part of the Minangkabau intellectual history. ${ }^{24}$ However, as alluded to above, our definition of "religious texts" needs to be reviewed if what is meant by that definition is all the manuscripts produced by scholars or religious institutions are limited to religious discourse in the conventional sense. The works of ulama or originating from religious institutions do not always contain religious teachings, but also literature, mathematics, and astronomy as well as a variety of experiences relating to everyday life..$^{25}$

Closely related to the Minangakabu manuscript above, our knowledge of religious movements before and after the Padri War (1803-1837), is usually very limited to Western (Dutch) sources. For example, as written by Muhammad Radjab (1958), ${ }^{26}$ Christine Dobbin (1983), ${ }^{27}$ and Rusli Amran $(1981,1985),{ }^{28}$ in addition to dozens of articles published in various scientific journals published at national and international levels. These studies generally rely on primary sources (Dutch document). Generally written in the form of military reports by military commanders, field troops, and also by private Dutch colonial officials who were involved directly or indirectly in the Paderi War (Suryadi, Singgalang 3-6 December 2006). ${ }^{29}$ Indigenous sources in the form of manuscripts about the Padri War, so far, are also available, but so far they have not been worked on.

Apart from the Memoar Imām Bonjol mentioned above, the manuscript of the Padri Movement written by the Minangkabau themselves who was directly involved in the movement, for example, is the "Surat Keterangan Sheikh Jalaluddin" by Fakih Saghir and another Manuscript of the Imām Bonjol. ${ }^{30}$ Both of these sources are quite high in historical value. We can see different perceptions and different points of view between the Minangkabau themselves and the Dutch about the Padri Movement. The two sources of indigenous texts, for example, can be compared to Dutch sources such as C.J. Boelhouwer who wrote Kenang-kenangan di Sumatera Barat during the years 18311834. The Manuscripts of the Faqih Saghir, among others, contain manners (adāb), politeness, and order in the relationship between students and teachers according to the tariqa Shatariyah. ${ }^{31}$ This text also describes the experience of Faqih Saghir according to what he saw, heard, and experienced, when the atmosphere of renewal and progress of the surau and trading period before and after the Dutch arrival in Padang, the interior of the Minangkabau took place at the turn of the 18th/19th century. In the Saghir Faqih text, there is also a story about the role of Tuanku Nan Tuo (1750-1832), as a charismatic figure, the prime mover who gave birth to the Islamic revival in Agam since the last part of the XVIII century. ${ }^{32}$

\footnotetext{
22 Isma'il Basya al-Baghdādi (1951), Hādyyat al- 'Ārifiñ: Asma' al-Mu'allifín wa Athar al-Mușannifiñn, Volume II, Istanbul: Milli Egitim Basim Basset, Rene, p. 300. See also 'Abdul Qādir Mandaili al-Indunisiy (2004), al-Khazāin al-Saniyyah min Mashāhir al-Kutub alFiqhiyyah li-Aimmatina al-Fuqaha' al-Shāfi '̄yyyah, Beirut: Muassasah al-Risālah, p. 80.

${ }^{23}$ Oman Fathurahman, Filologi dan Islam Indonesia.

${ }^{24}$ Haji Khalifah, Kashf al-Zunnun 'an Asami al-Kutub Wal al-Funun, p. 5.

${ }^{25}$ Haji Khalifah, Kashf al-Zunnun 'an Asami al-Kutub Wal al-Funun. p.5

${ }^{26}$ Muhammad Radjab (1958), Tjatatan di Sumatera, Djakarta: Balai Pustaka.

${ }^{27}$ Christine Dobbin (1983), Islamic Revivalism in a Changing Peasant Economy: Central Sumatra 1784-1847, Denmark: Curzon PressScandinavian Institute of Asian Studies.

${ }^{28}$ Rusli Amran (1981), Sumatera Barat Hingga Plakat Panjang, Jakarta: Sinar Harapan.

${ }^{29}$ Suryadi (2007), "Siapakah Kini Yang Menyimpan Naskah Asli Tuanku Imam Bonjol?" Indonesian Islamic Philology, accessed $20^{\text {th }}$ January 2021, http://oman.uinjkt.ac.id/2007/02/siapakah-kini-yang-menyimpan-naskah.html.

${ }^{30}$ Sjafnir Aboe Nain (2004), Naskah Tuanku Imam Bonjol, Padang: Pusat Pengkajian Islam dan Minangkabau.

${ }^{31}$ Haji Khalifah, Kashfal-Žhunnun 'an Asami al-Kutub Wal al-Funun, p. 5.

${ }^{32}$ Haji Khalifah, Kashf al-Zhunnun 'an Asami al-Kutub Wal al-Funun, p. 7.
} 
The Padri Movement in this text provides a completely different picture than the Dutch reported. For the Dutch, the movement was a radical fanatic group, which opposed the adat faction, by giving birth to a dichotomic interpretation between the adat versus the religious faction as two groups with philosophy and then grows into "rebels" against the colonial regime. In the middle of Faqih Saghir's advice, the movement was more of a thought changes movement, known as "returning to the shari'a" which was pioneered by Tuanku Nan Tuo from Ampek Angkek, Agam. This figure is considered a defender of "orthodoxy fiqh," which is moderate, encourages obedience to fiqh, and opposes everything that smells of heresy. The movement has a base in the surau as part of traditional and religious institutions that are integrated with the structure of the Nagari community. ${ }^{33}$ The Dutch error in seeing the social structure of the Minangkabau was also followed by more later writers due to the absence of a comparative source of indigenous texts.

\section{Manuscript Study in Islamic Thought; Philosophy (Manțiq) and Sufism}

The explanation provided by Syeikh Abdurrauf revealed that he is a figure of an Islamic scholar who accepts the teaching of Wahdat al-Wujüd based on rules that he wrote (manuscript of Pondok Ulakan Pariaman); hence, it has a bigger chance that this teaching is developing in Minangkabau. Moreover, before the production of this writing, the writing that describes the concept of tanzìh and tashbinh has been written. The writing was written by the teacher of Abdurrauf, Sheikh Ibrahim al-Kurani due to the request of Sheikh Abdurrauf himself, entitled It tâf al-Dhākiy. ${ }^{34}$ Based on this, there occur probability to compare the thought of Sheikh Ibrahim al-Kurani and Sheikh Abdurrauf toward the concept of wujüdiyah.

Based on manuscripts related to thought, philosophy (mantīq), and Sufism, the Shatariyah is a tariqa that prioritizes philosophical studies to be able to draw closer to God or to get to know the Creator (ma 'rifät) ${ }^{35}$ This philosophical study is closely related to beliefs or creeds ('aqidah) about "Who is the God who created this universe". The teachings on cosmology and metaphysics are characteristic of the tariqa Shatariyah in Minangkabau ${ }^{36}$ In the world of Sufism, the study of divinity adhered to by the tariqa Shatariyah is included in philosophical Sufism with its main concept being "wujüdyah" which is called "Martabat Tujuh" or "kaji tubuh".

Texts about the teachings of the Martabat Tujuh are very much found in Minangkabau, in addition to text copies of the ideas of previous scholars such as Sheikh Abdurauf, Sheikh Syamsuddin Sumatera, and Hamzah Fansuri, there are texts containing local thoughts related to the Martabat Tujuh. This can be known from several texts regarding the teachings of the Martabat Tujuh that have different ways and analogies in explaining the essence of the teaching.

Figure 2. Futuhät al-Ilähiyah Text

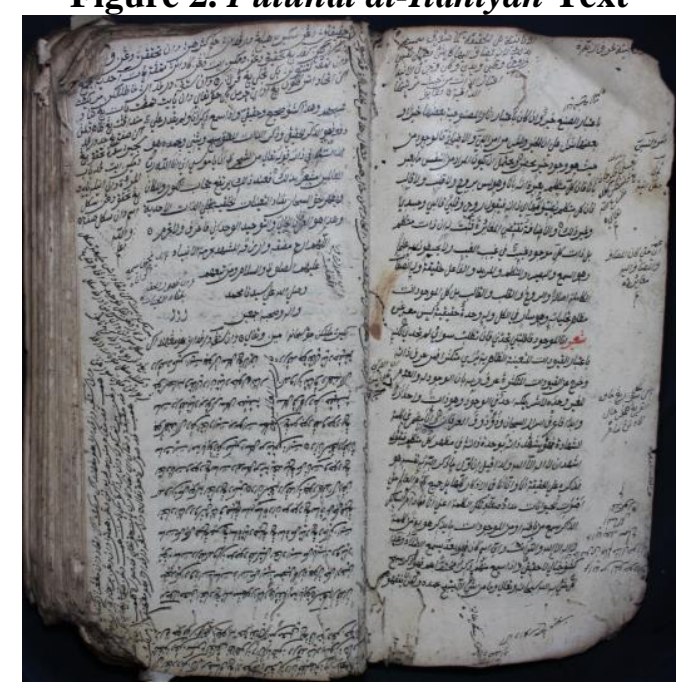

\footnotetext{
33 Observation and Personal Interview with Buya Muzardin Musthafa Kamal, 20 th October 2019, Surau Lubuk Landur Pasaman.

${ }^{34}$ Oman Fathurahman (2011), "Ithāāf Al-Dhakī by Ibrāhīm al-Kūrānī: A Commentary of Wahdat al- Wujūd for Jāwī Audiences," Archipel, Vol. 81, 177-198.

35 Anne K. Bang (2003), Sufis and Scholars of the Sea: Family Networks in East Africa, 1860-1925, London: Routledge.

${ }^{36}$ Sokhi Huda (2008), Tasawuf Kultural: Fenomena Shalawat Wahidiyah, Yogyakarta: LkiS, p. 37.
} 
Based on this, it can be assumed that the teachings of wujüdyah can reach Minangkabau with the services of Sheikh Burhanuddin as the transmission gate of this teaching. Even in the issue of wujüdyah, many historians argue that Sheikh Abdurrauf himself rejected this teaching so that Sheikh Burhanuddin is one of the scholars who did not teach the concept of wujüdyah to Minangkabau. ${ }^{37}$ This is different from the manuscripts found in Minangkabau which very much talk about the concept of wujüdyah, even Sheikh Abdurrauf wrote a work explaining the concept of wahdat al-wujūd. The work written by Sheikh Abdurrauf is entitled Kifāyat al-Muhtajīn ila Mashrab al-Mawhidīn biy Wahdat al-Wujūd. In this work Sheikh Abdurrauf explains about wahdat al-wujūd as above:

...So the result of combining between the two is knowing and believing that Allah Subhanahu wa ta'āla gathers between all the opposite attributes as said by Sheikh Ibn Said Ahrar when people asked him about "Do you know God Almighty?" then the answer bijam'ahu baina al-didain means with it combining two opposites, then it is indicated by his words that which is interpreted by the Word of Allah ta'āla huwa alawwal wa al-ākhir wa al-zāhir wa al-bāthin means he is the first and he is the last and the zāhir and the bāțin, then there is no God can gather them all except Allah. So whoever understands this Word of Allah is certainly from those who gather between the enlightenment of tanzī and tashbịh, so that is why it is named by some scholars muhaqqīin to all of them the mother of all truth // and the perfect enlightenment and this is the best evidence that points to wahdat al-wujūd..$^{38}$

Based on the explanation given by Sheikh Abdurrauf above, it can be known that he is a figure of scholars who accept the teachings of wahdat al-wujüd based on the signs he wrote above. So this teaching most likely developed in Minangkabau. In addition, before his work was written, there was first a work that explained the concept of tanzīh and tashbīh. The work was written by Abdurrauf's teacher, Sheikh Ibrahim al-Kurani at the request of Sheikh Abdurrauf himself, work is entitled Ithāf al-Dzakiy. ${ }^{39}$ Based on this, there is an opportunity to compare the thinking between Sheikh Ibrahim al-Kurani and Sheikh Abdurrauf on this concept of wujudiyah.

Then, the study of mantīi in the text of Minangkabau scholars, for example in the book al-Sawānih al-Jāzimah fi at-Ta'arīf al-Lāzimah, written by Sheikh Muhammad 'Ali ibn Almarhum Sheikh Husain. The study begins by discussing the foundation that is the basis of logic, emphasizing that everyone with an intelligent brain automatically thinks logically without having to learn logically. ${ }^{40}$ In terms of 'aqliyah, it is proven that intelligent human beings who talk about science can decipher their knowledge without Greek logic. Religiously, anyone knows that religion never requires us to learn logic.

The rejection of the Greek mantī $q$ is related to the objection to definition; whether it is true that knowledge of tașawwuriy cannot be obtained without a logical definition with its five universes (kulliyat al-khams), namely genus (jins), a difference (fașl), species (nau ), general accident ('ardh 'am) and special accident ('ardh khaș). In connection with this objection, there is also criticism to refute some statements: First, affirmation (nāfi), as well as determination (ithbāt), if not axiomatic then should be based on evidence. Since there is no evidence to support it, this statement must be rejected; second, if the definition is the speech of a definition maker, then he has known the object to be defined by definition or not. ${ }^{41}$ If so, then it is obligatory for the argument to rotate and chain (tasalsul) which will not run out. If not, then the negation canceled; thirdly, the conception of reality cannot be done except through the essential definition which consists of universal essence (mushtarakah) and sorting (mutamayyizah), which are composed of genus and difference, and this is impossible or very difficult as their recognition. Thus, it is impossible or very difficult to

\footnotetext{
${ }^{37}$ Oman Fathurahman (1994), Menyoal Wahdatul Wujud, Bandung: Mizan, p. 24.

${ }^{38}$ Manuscript in Surau Pondok Ulakan Pariaman. Observation and Personal Interview with Heri Firmansyah Tuanku Khalifah, $26^{\text {th }}$ October 2019, Surau Pondok Ulakan Pariaman; Ahmad Taufik Hidayat (2011), Katalog Naskah Pasaman, Surau Lubuk Landur dan Masjid Sheikh Bonjol, Padang: PT Tintamas-Komunitas SULUAH.

${ }^{39}$ Oman Fathurahman, "Itḥāf Al-Dhakī by Ibrāhīm al-Kūrānī."; Ahmad Taufik Hidayat (2014), Katalog Surau II: Panduan Koleksi Naskah Pusaka Syekh Burhanuddin Ulakan Surau Pondok Tanjung Medan, Padang: Imam Bonjol Press.

${ }^{40}$ Observation and Personal Interview with Heri Firmansyah Tuanku Khalifah, $27^{\text {th }}$ October 2019, Surau Pondok Ulakan Pariaman.

${ }^{41}$ Kitāb Manțī in Surau Pondok Ulakan Pariaman. Observation and Personal Interview with Heri Firmansyah Tuanku Khalifah, 27 October 2019, Surau Pondok Ulakan Pariaman.
} 
conceptualize reality, even though it is proven that reality can be conceptualized by humans, then their statement canceled; fourth, conceptual objects can be known by the senses of birth (such as color, taste, and smell) or by the inner senses (such as hunger, love, hate, desire, etc.). All this can be known without the need for a definition. Thus, nullify their statement that conception (tașawwurīy) cannot be achieved without definition.

The definition provides no knowledge about the truth, but it is to differentiate one from another. For example, the definition of a name is aimed to make a distinction between one individual to other individuals without necessarily explaining the truth or the essence of it. This can be proved such as; first, the definition is only the statement of the creator without proof. Once a person said that "human is an animal that thinks," this is only an informative sentence without proof. Second, it is impossible to prove the definition, but it is possible to challenge it. This is because it is hard for a person to reveal something defined without the utterance, meanwhile, the utterance contains the probability of true and false; hence, a person may refuse to accept it.

So far for the Minangkabau manuscript, ${ }^{42}$ the study of codicology in general is only limited to presenting a catalog, such as: E.P Wieringa, Catalogue of Malay and Minangkabau Manuscripts in the Library of Leiden University and other Collections in the Netherlands, published in 1998; Teuku Iskandar: Catalogue of Malay, Minangkabau and South Sumatran Manuscripts in the Netherlands, published in 1999 in the Netherlands by Documentatiebureau Islam-Christendom; P.S van Ronkel, Supplement-Catalogus der Maleische en Minangkabausche Handschriften in de Leidsche Universiteits-bibliothek, published by Brill in 1921; M. Yusuf (ed.), Katalogus Manuskrip dan Skriptorium Minangkabau which was published in 2006 in collaboration with C-DATS Tokyo with the Poetry Study of Andalas University; Ahmad Taufik Hidayat, et al., Katalog Naskah Pasaman, Surau Lubuk Landur dan Masjid Sheikh Bonjol published in 2011 by PT Tintamas dan Komunitas SULUAH; Ahmad Taufik Hidayat, dkk, Katalog Surau II: Panduan Koleksi Naskah Pusaka Syekh Burhanuddin Ulakan Surau Pondok Tanjung Medan, published in 2014 by Imam Bonjol Press; T.E Behrend (ed.), Katalog Induk Naskah-Naskah Nusantara, published in 1997 by Yayasan Obor Indonesia, and a number of other catalogs containing Minangkabau manuscripts.

Codicology as the basis of the discipline can be optimized in the study development at Islamic studies institution since there are lots of historical information found in this particular study. For example, in the discourse of fiqh madhhab, theology, and religious ideology. Generally, the tendency of study at the Islamic studies institutions is merely based on the aspect of scientific genealogy and narrative. The proof of the authenticity of the source based on the physical script with all the variety of cultures it shows, that can be dismantled through phenomena outside the text in the manuscript, madhhab distribution channel, and investigable religious ideology via the manuscript is often neglected. The same thing also happens to the place to write and to copy the script (scriptorium) that provides wide information about cultural construction, which is also a place to produce an idea, however, this place is seldom to be used in the research conducted by Islamic studies institutions. Often, the failure in understanding text phenomenon tends to be caused by a lack of information about this.

The serious effect of the neglect of this aspect is that the serious claims proposed in a sequence of research tend to be easily rejected. However, when the claims are supported by valid data of codicology, such as watermark, colophon, script trade, the history of scriptwriting, and all aspects of culture explained in the physical script will help to strengthen the claim of the researcher or the manuscript investigator.

\section{Conclusion}

Paratext approach to manuscripts, especially for the Minangkabau region and its surroundings for Islamic studies institutions can be done without being tied to a single discipline, such as Philology.

\footnotetext{
${ }^{42}$ Andrew Gosling, (2000), "Katalog Induk Naskah-Naskah Nusantara Jilid 4. Perpustakaan Nasional Republik Indonesia (Union Catalogue of Indonesian Manuscripts, Vol. 4, National Library of Indonesia). Edited by T.E. Behrend, Jakarta: Yayasan Obor Indonesia, Ecole Francaise d'Extrem," Journal of Southeast Asian Studies; C.O., Vol. 31, No. 1, 192; Blagden (1921), "Supplement-Catalogus Der Maleische En Minang-Kabausche Handschriften in de Leidsche Universiteits-Bibliotheek," Journal of the Royal Asiatic Society, Vol. 53, No. 4, p. 646.
} 
As a means of interpretation, or a tool for interpreting the context of a text in a manuscript, of course, this kind of study needs to be developed extensively.

The manuscripts found in the Minangkabau region authentically play a role in understanding, studying, interpreting, planning, and engineering the socio-religious aspects in the context of cultural, religious, and society. This is the background of the content found in the Manuscript and the sociohistorical aspects that connect with various regions in the archipelago. Therefore, the various categories of study scope in Minangkabau manuscripts reflect the vast system of religious social interaction experience that once existed in the Minangkabau community, so that Islamic studies institutions.

The existence of manuscripts in research-based studies for the development of scientific studies in Islamic studies institutions or Islamic research institutions found in Bani Lathif Balai Gurah Agam; Surau Pondok Ulakan Pariaman; and Surau Lubuk Landur Pasaman. All the manuscripts are related to the following studies: Tafsīr and Hadīth; related to Shari'a knowledge can be found in various texts included in the category of fiqh; related to the Islamic thought, philosophy, and logic in the categories of ușūluddin and logic; lastly, related to Arabic historical.

\section{Recommendation}

Minangkabau is a customary area with tradition that mandates the substance to strengthen traditional and religious values and strengthen their implementation, as stated in the philosophy of "Adat Basandi Syara' and Syara' Basandi Kitabullah". Essentially this mandate wants to create a civilized society in addition to being faithful, intelligent and wants to strengthen the social, economic, political, and cultural institutional capacity. Therefore, Islamic studies institutions as one of the higher education institutions that exist, live, and grow up in the Minangkabau area, it is time to be more concerned and focused on addressing the manuscripts in the Minangkabau area, so that it can be seen the form of the science curriculum. Islam in Minangkabau; even the books found can be used as reference and study.

\section{References}

Abushouk, Ahmed Ibrahim and Hassan Ahmed (eds.) (2009), The Hadhrami Diaspora in Southeast Asia: Identity Maintenance or Assimilation?, Leiden and Boston: Brill.

Akhimuddin, Yusri (2012), "Naskah (Asal Khilaf Bilangan Taqwim): Relasi Ulama-Umara di Minangkabau Abad Ke-17 dalam Penetapan Awal Ramadan,” Manuskripta, 79-101.

Amran, Rusli (1981), Sumatera Barat Hingga Plakat Panjang, Jakarta: Sinar Harapan.

Bang, Anne K. (2003), Sufis and Scholars of the Sea: Family Networks in East Africa, 1860-1925, London: Routledge.

Al-Baghdādi, Isma'il Basya (1951), Hādyyat al- 'Ārifìn: Asma' al-Mu 'allifìn wa Athar al-Mușannifin, Volume II, Istanbul: Milli Egitim Basim Basset, Rene.

Baried, Siti Baroroh (1994), Pengantar Teori Filologi, Yogyakarta: Badan Penelitian dan Publikasi Fakultas Sastra, Universitas Gadjah Mada.

Blagden, C.O. (1921), "Supplement-Catalogus Der Maleische En Minang-Kabausche Handschriften in de Leidsche Universiteits-Bibliotheek," Journal of the Royal Asiatic Society, Vol. 53, No. 4, 646.

Braginsky, Vladimir (1998), Yang Indah Berfaedah dan Kamal, Sejarah Sastera Melayu dalam Abad 7-19, Jakarta: INIS.

Dhaif, Syauqi (2008), al-Mu 'jam al-Wasit, Mesir: Maktabah ash-Shauqi al-Dauliyah. 
The Existence of the Manuscript in Minangkabau Indonesia and Its Field in Islamic Studies

Dobbin, Christine (1983), Islamic Revivalism in a Changing Peasant Economy: Central Sumatra 1784-1847, Denmark: Curzon Press-Scandinavian Institute of Asian Studies.

Fathurahman, Oman (2013), "A Textual Approach to Understanding Nusantara Muslims," Studia Islamika, Vol. 20, No. 1, 179-182.

Fathurahman, Oman (2010), Filologi dan Islam Indonesia, Jakarta: Kementerian Agama. Badan Penelitian (Litbang) dan Pendidikan Pelatihan (Diklat). Pusat Penelitian Pengembangan (Puslitbang) Lektur Keagamaan).

Fathurahman, Oman (2003), "Filologi dan Penelitian Teks-teks Keagamaan," Buletin al-Turas, Vol. 9, No. 2, 1-16.

Fathurahman, Oman (2015), Filologi Indonesia: Teori dan Metode, Jakarta: Prenadamedia Group.

Fathurahman, Oman (2011), "Itḥāf Al-Dhakī by Ibrāhīm al-Kūrānī: A Commentary of Waḥdat alWujūd for Jāwī Audiences," Archipel, Vol. 81, 177-198.

Fathurahman, Oman (1994), Menyoal Wahdatul Wujud, Bandung: Mizan.

Fathurahman, Oman (2003), "Reinforcing Neo-Sufism in the Malay-Indonesian World: Shaț̣ārīyah Order in West Sumatra," Studia Islamika, Vo. 10, No. 3, 29-93.

Fathurahman, Oman (2014), "Tradisi Intelektual Islam Melayu-Indonesia: Adaptasi dan Pembaharuan," Studia Islamika, Vol. 8, No. 3, 207-222.

Hamid Abu Zaid, Nasr (2003), Tekstualitas Alquran, Kritik Terhadap Ulum Alquran, Yogyakarta: LkiS.

Hidayat, Ahmad Taufik (2011), Katalog Naskah Pasaman, Surau Lubuk Landur dan Masjid Sheikh Bonjol, Padang: PT Tintamas-Komunitas SULUAH.

Hidayat, Ahmad Taufik (2014), Katalog Surau II: Panduan Koleksi Naskah Pusaka Syekh Burhanuddin Ulakan Surau Pondok Tanjung Medan, Padang: Imam Bonjol Press.

Hidayatullah, Dede (2017), "Naskah Ilmu Ma'rifatullah: Kodikologi, Suntingan, Struktur, dan Isi Teks The Manuscript of Ilmu Ma'rifatullah: Codicology, Editing, Structure, and Content," Metasastra: Jurnal Penelitian Sastra, Vol. 9, No. 2, 107-116.

Huda, Sokhi (2008), Tasawuf Kultural: Fenomena Shalawat Wahidiyah, Yogyakarta: LkiS.

Gosling, Andrew (2000), "Katalog Induk Naskah-Naskah Nusantara Jilid 4. Perpustakaan Nasional Republik Indonesia (Union Catalogue of Indonesian Manuscripts, Vol. 4, National Library of Indonesia). Edited by T.E. Behrend, Jakarta: Yayasan Obor Indonesia, Ecole Francaise d'Extrem," Journal of Southeast Asian Studies; C.O., Vol. 31, No. 1, 192-193.

Al-Indunisiy, 'Abdul Qādir Mandaili, (2004), al-Khazāin al-Saniyyah min Mashāhir al-Kutub alFiqhiyyah li-Aimmatina al-Fuqaha' al-Shāfi '̌̃yyah, Beirut: Muassasah al-Risālah.

Iswanto, Agus (2016), "Kecenderungan Kajian Manuskrip Keislaman di UIN Syarif Hidayatullah Jakarta," al-Qalam, Vol. 21, No. 1, 161-171.

J. Moleong, Lexy (2002), Metode Penelitian Kualitatif, Bandung: Remaja Rosdakarya.

Jabali, Fuad, (2014), "Irsā Al-Usus al-'Ilmīyah Li al-Dirāsat al-Islāmīyah: Al-Taṭawwur al-Akādīmī Li al-Jāmi'at al-Islāmīyah al-Ḥukūmīyah Wa al-Ma'āhid al-Islāmīyah al-Ḥukūmīyah al-'Ulyā bi Indūn̄̄sìyā," Studia Islamika, Vol. 9, No. 2, 121-146. 
Khalifah, Haji (n.d.), Kashf al-Zunnun 'an Asami al-Kutub Wal al-Funun, Vol. II, Beirut: Dar Ihya' al-Turath al-'Araby.

Lubis, Nabilah (1996), Naskah, Teks, Dan Metode Penelitian Filologi, Jakarta: Forum Kajian Bahasa \& Sastra Arab, Fakultas Adab IAIN Syarif Hidayatullah.

Luthfi, Khabibi Muhammad (2016), "Kontekstualisasi Filologi dalam Teks-teks Islam Nusantara," Jurnal Kebudayaan Islam, Vol. 14, No. 1, 114-128.

Marlow, Christine R. (2010), Research Methods for Generalist Social Work, Cengage Learning.

Metcalf, Barbara Daly (1993), "Living Hadīth in the Tablīghī Jama'ât," The Journal of Asian Studies, Vol. 52, No. 3, 584-608.

Moleong, Lexy J. (2004), Metode Penelitian Kualitatif, Bandung: Remaja Rosdakarya.

Nain, Sjafnir Aboe (2004), Naskah Tuanku Imam Bonjol, Padang: Pusat Pengkajian Islam dan Minangkabau.

Observation and Personal Interview with Buya Ismet, $19^{\text {th }}$ October 2019, Surau Manggopoh Agam.

Observation and Personal Interview with Buya Muzardin Musthafa Kamal, 20 ${ }^{\text {th }}$ October 2019, Surau Lubuk Landur Pasaman.

Observation and Personal Interview with Heri Firmansyah Tuanku Khalifah, $26^{\text {th }}$ and $27^{\text {th }}$ October 2019, Surau Pondok Ulakan Pariaman.

Pudjiastuti, Titik (2007), "Kajian Kodikologis Atas Surat Sultan Kanoman, Cirebon (COD. OR. 2241 ILLB 17 (No. 80)," Wacana: Journal of the Humanities of Indonesia, Vol. 9, No. 1, 51-61.

Pudjiastuti, Titik (2006), Naskah Dan Studi Naskah: Sebuah Antologi, Cimanggis, Bojonggede, Bogor: Akademia.

Qudsy, Saifuddin Zuhri (2016), "Living Hadis: Genealogi, Teori, dan Aplikasi," Jurnal Living Hadis, Vol. 1, No. 1, 177-196.

Radjab, Muhammad (1958), Tjatatan di Sumatera, Djakarta: Balai Pustaka.

Republik Indonesia (2007), “Undang-undang Tentang Perpustakaan,” Jakarta.

Sudibyo (2007), “Kembali Ke Filologi : Filologi Indonesia,” Humaniora, Vol. 19, No. 2, 107-118.

Sugono, D (2008), Kamus Bahasa Indonesia, $4^{\text {th }}$ edition, Jakarta: Pusat Bahasa Depatemen Pendidikan Nasional.

Suryadi (2007), “Siapakah Kini Yang Menyimpan Naskah Asli Tuanku Imam Bonjol?” Indonesian Islamic Philology, accessed $20^{\text {th }}$ January 2021, http://oman.uinjkt.ac.id/2007/02/siapakah-kini-yangmenyimpan-naskah.html.

Sutopo, Heribertus (1988), Pengantar Penelitian Kualitatif: Dasar-dasar Teoritis dan Praktis, Surakarta: UNS Press.

Yusuf, M. (2006), Katalogus Manuskrip dan Skriptorium Minangkabau. Padang: C-DATS TokyoKajian Puitika Unand. 